\title{
PROTOTIPE SISTEM PENGUKUR DAYA PERALATAN LISTRIK
}

\author{
Wisnu Djatmiko ${ }^{1, a)}$ \\ ${ }^{1}$ Program Studi Pendidikan Teknik Elektronika, Fakultas Teknik - Universitas Negeri Jakarta \\ Kampus Universitas Negeri Jakarta Jalan Rawamangun Muka, Jakarta Timur (13220) \\ Email: ${ }^{a)}$ wisnu.dj@unj.ac.id
}

\begin{abstract}
Abstrak
Sebuah prototipe sistem pengukur daya berbasis Arduino Uno diusulkan untuk mengukur dan menampilkan daya semu (apparent power - S) peralatan listrik. Prototipe sistem yang diusulkan direalisasikan menggunakan 4 sub-sistem: (1) sensor $\mathrm{V}_{\mathrm{MAX}}$ menggunakan rangkaian full-wave rectifier dengan beban fixed-resistor yang dihubungkan ke Arduino; (2) sensor $\mathrm{I}_{\mathrm{RMS}}$ menggunakan $5 A$ noninvansive AC current sensor module yang dihubungkan ke Arduino; (3) modul LCD 20x4 character dengan koneksi $\mathrm{I}^{2} \mathrm{C}$; dan (4) Arduino Uno board. Arduino digunakan untuk membaca $\mathrm{V}_{\mathrm{MAX}}$ (keluaran full-wave rectifier), $\mathrm{V}_{\mathrm{RMS}}$ (keluaran $5 A$ non-invansive AC current sensor module) selama $20 \mathrm{mS}$ dan kemudian dikonversikan menjadi $\mathrm{V}_{\mathrm{RMS}}$ dan $\mathrm{I}_{\mathrm{RMS}}$ dan kemudian nilai daya semu dihitung menggunakan persamaan $\mathrm{S}=\mathrm{I}_{\mathrm{RMS}} \times \mathrm{V}_{\mathrm{RMS}}$. Nilai $\mathrm{V}_{\mathrm{RMS}}, \mathrm{I}_{\mathrm{RMS}}$, dan $\mathrm{S}$ ditampilkan ke LCD. Prototipe sistem pengukur daya peralatan listrik telah selesai dibuat, diuji, dan dibandingkan dengan menggunakan multifunctional mini ammeter WanF® DO2A dapat mengukur daya semu peralatan listrik rumah-tangga dengan rentang dari 61 Watts sampai dengan 380 Watts dengan nilai \% kesalahan pengukuran sebesar $\pm 10 \%$.
\end{abstract}

Kata-kata kunci: sistem pengukur daya semu, sensor $\mathrm{V}_{\mathrm{RMS}}$, sensor $\mathrm{I}_{\mathrm{RMS}}$, aplikasi Arduino.

\begin{abstract}
A prototype of power meter system based-on Arduino is proposed for measuring apparent power (S). The proposed system is realized using 4 sub-systems: (1) $V_{\text {MAX }}$ sensor based-on full-wave rectifier (with fixed-resistor loads) connected to Arduino; (2) $\mathrm{I}_{\mathrm{MAX}}$ sensor based-on 5A non-invansive AC current sensor module connected to Arduino; (3) 20x4 character LCD display module based-on Hitachi IC HD44780 with $\mathrm{I}^{2} \mathrm{C}$ connection; and (4) Arduino Uno board. Arduino is used to read $\mathrm{V}_{\mathrm{MAX}}$ (full-wave rectifier output), and $\mathrm{V}_{\mathrm{RMS}}$ (output $5 \mathrm{~A}$ non-invansive $\mathrm{AC}$ current sensor module) for $20 \mathrm{mS}$ and then converted to $V_{R M S}$ and $I_{R M S}$ and then apparent power value calculated using $S=I_{R M S} \times V_{R M S}$ equation. The prototype of apparent power meter system has been build, tested and compared using the multifunctional mini ammeter $\mathrm{WanF} \circledast \mathrm{DO} 2 \mathrm{~A}$ can measure the apparent power of electrical appliances with a range from 61 Watts to 380 Watts with $\pm 10 \%$ error measurement.
\end{abstract}

Keywords: Apparent power measuring system, $\mathrm{V}_{\mathrm{RMS}}$ sensor, $\mathrm{I}_{\mathrm{RMS}}$ sensor, Arduino application.

\section{PENDAHULUAN}

Peralatan elektronik yang memerlukan daya besar (>100VA) banyak digunakan pada jenis pelanggan rumah-tangga (R-1 sampai dengan R-3) dan dapat diketahui nilai daya listriknya dengan cara melihat di spesifikasi alat (name plate) atau diukur menggunakan Watt meter. Daya listrik semu (Volt Ampere) pada beberapa peralatan listrik dapat tidak sesuai dengan daya yang tertera pada 
name plate (dapat mempunyai nilai yang lebih rendah atau lebih tinggi) pada awal atau setelah beberapa saat peralatan listrik tersebut dioperasikan. Watt meter diperlukan untuk mengetahui daya semu peralatan listrik sehingga pelanggan PLN dapat memperoleh data yang dapat dijadikan dasar untuk membuat jadwal penggunaan peralatan listrik supaya dapat meminimalkan terjadinya gangguan listrik yang disebabkan MCB-OFF karena kelebihan daya.

Gelombang listrik $\mathrm{AC}$ (gelombang $\mathrm{V}_{\mathrm{P}}$, $\mathrm{I}_{\mathrm{P}}$, dan $\mathrm{P}$ ) dengan beban resistif murni akan mempunyai fase yang sama (beda phase $=0^{\circ}$ ) sehingga mempunyai nilai faktor daya atau $\cos \emptyset=1$ dan menyebabkan daya listrik yang diserap dari sumber energi listrik memiliki nilai yang selalu positif (Gambar 1.a). Hubungan antara daya nyata (real power - W), daya reaktif (reactive power - VAR) dan daya semu (apparent power - S) dapat direpresentasikan oleh vektor-vektor seperti ditunjukkan pada Gambar 1.b dan hubungan antara daya semu, $V_{R M S}$, dan $I_{R M S}$ pada sisi beban akan memenuhi persamaan (1)[1]. Dari teori tersebut dapat disimpulkan bahwa jika tegangan $\mathrm{V}_{\mathrm{RMS}}$ dan $\mathrm{I}_{\mathrm{RMS}}$ pada peralatan listrik dapat diperoleh, maka besarnya daya semu yang mengalir akan dapat dihitung dengan menggunakan persamaan (1).

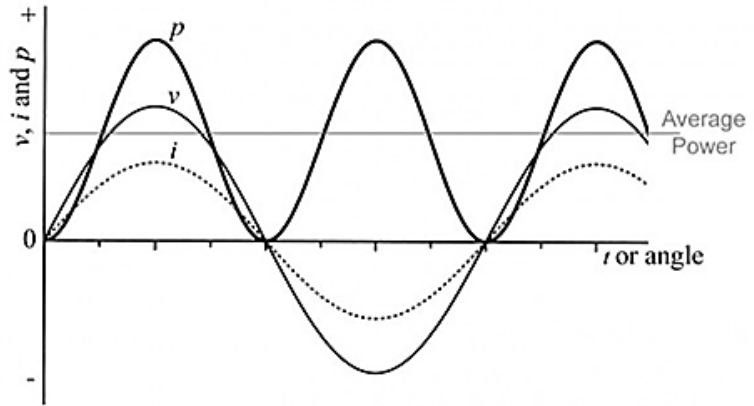

(a)

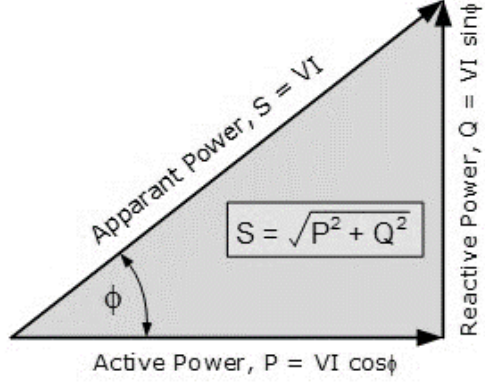

(b)

GAMBAR 1. (a) bentuk gelombang $V_{P}, I_{P}$, dan daya nyata, (b) komponen-komponen daya listrik AC.

$$
S(\text { apparent power })=V_{R M S} \times I_{R M S}
$$

Nilai tegangan effektif atau $\mathrm{V}_{\mathrm{RMS}}$ pada beban dapat diketahui dengan menggunakan rangkaian penyearah gelombang penuh berbasis diode bridge yang langsung dihubungkan ke sumber tegangan listrik dan tegangan keluarannya dihubungkan ke resistor (Gambar 2.a)[2][3]. Jika sumber tegangan jala-jala listrik dengan fungsi gelombang sinusoidal dihubungkan ke masukkan, maka bentuk tegangan keluaran pada beban resistor akan mempunyai bentuk gelombang seperti ditunjukkan pada Gambar 2.b. Nilai $\mathrm{V}_{\mathrm{MAX}}$ akan mencapai nilai puncak saat $\omega t=\pi / 2$ dan mencapai nilai minimal saat $\omega t=0^{\circ}$ atau kelipatan dari $\pi$, dan level tegangan $V_{\mathrm{RMS}}$ di beban diperoleh dari penurunan persamaan (2) sampai (4)[3][4].

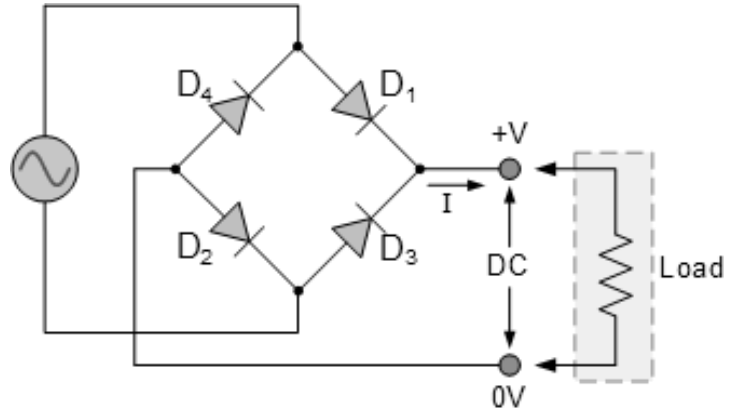

(a)

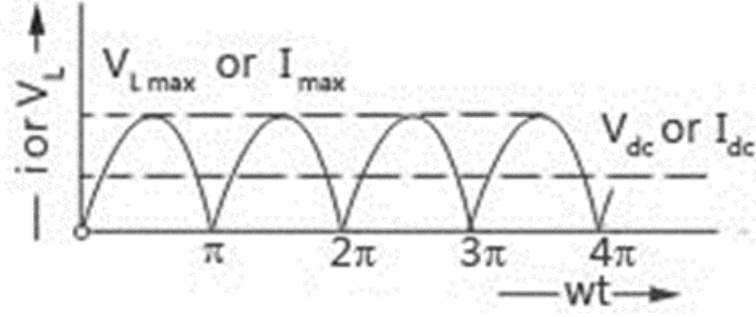

(b)

GAMBAR 2. (a) rangkaian penyearah gelombang penuh menggunakan diode bridge,

(b) bentuk arus pada beban resistor. 


$$
\begin{gathered}
V_{R M S}{ }^{2}=\frac{1}{T} \int_{0}^{\pi} V_{i n}(t)^{2} d t \\
V_{R M S}=\sqrt{\frac{1}{\pi} \int_{0}^{\pi}\left(V_{M A X} \sin \omega t\right)^{2} d t} \\
V_{R M S}=\frac{V_{M A X}}{1,4142}=0,7071 V_{M A X} \\
V_{M A X}=I_{M A X} \times 200 \Omega \\
V_{R M S}=0,7071 \times V_{M A X} \\
I_{R M S}=\frac{V_{R M S}}{200 \Omega}
\end{gathered}
$$

Pulsa-pulsa keluaran (Gambar 2.b) dengan nilai tegangan puncak tertentu hanya terjadi setiap satu siklus atau setiap $10 \mathrm{mS}$ (lebar satu periode gelombang tegangan listrik atau frekuensi $100 \mathrm{~Hz}$ ), sehingga untuk menghitung nilai $\mathrm{V}_{\text {MAX }}$ dan merubahnya menjadi $\mathrm{V}_{\text {RMS }}$ maka tegangan $\mathrm{V}_{\text {MAX }}$ tersebut dapat dihubungkan ke kaki analog Arduino untuk dibaca dan dikonversikan menjadi data digital [5]. $\mathrm{V}_{\mathrm{MAX}}$ minimal dibaca selama $20 \mathrm{mS}$ menggunakan fungsi millis () untuk memastikan $\mathrm{V}_{\text {MAX }}$ dapat dideteksi dan kemudian dikonversi menjadi data digital menggunakan ADC-10 bit internal Arduino Uno dan dikonversi menjadi $\mathrm{V}_{\mathrm{RMS}}$ menggunakan persamaan (6) [3].

Besarnya arus effektif atau $\mathrm{I}_{\mathrm{RMS}}$ dapat diukur menggunakan 5A non-invansive AC current sensor module (Gambar 3.a) dengan cara melewatkan sebuah kawat atau penghantar yang dialiri arus listrik melalui loading coil. Terdapat sebuah resistor dengan nilai $200 \Omega$ (Gambar 3.b) yang dihubungkan secara paralel dengan loading coil sehingga saat terdapat arus pada loading coil, maka akan terdapat tegangan AC pada kaki-kaki terminal keluaran modul [5].

Dengan menggunakan data-data spesifikasi dari 5A non-invansive AC current sensor module, dapat disimpulkan bahwa jika terdapat arus gelombang sinus yang mengalir pada sebuah kawat (dengan arus $\mathrm{I}_{\mathrm{P}}$ atau $\mathrm{I}_{\mathrm{MAX}}$ ) yang diletakkan di loading coil, maka akan terdapat tegangan $\mathrm{V}_{\mathrm{MAX}}$ (atau $\mathrm{V}_{\mathrm{P}}$ ) di kaki keluaran modul dan dapat diubah menjadi tegangan $\mathrm{V}_{\mathrm{RMS}}$ dan $\mathrm{I}_{\mathrm{RMS}}$ menggunakan persamaan (5) sampai (7). Tegangan $\mathrm{V}_{\mathrm{MAX}}$ keluaran $5 \mathrm{~A}$ non-invansive $\mathrm{AC}$ current sensor module dihubungkan ke masukan analog Arduino Uno untuk dibaca selama $20 \mathrm{mS}$ (menggunakan fungsi millis()) dan kemudian dikonversikan menjadi data digital dan dapat dihitung $\mathrm{I}_{\mathrm{RMS}}$ dengan menggunakan persamaan (7)[5].

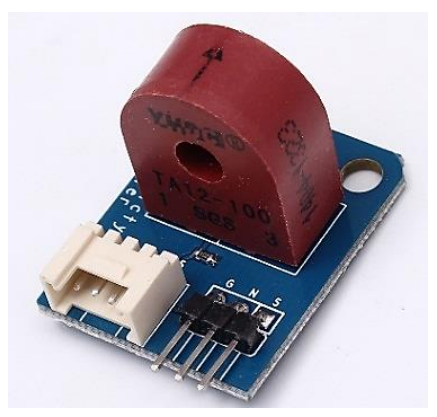

(a)

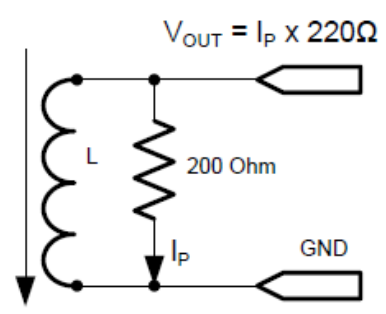

(b)

GAMBAR 3. 5A Non-invansive AC current sensor module (a) bentuk fisik, (b) rangkaian elektronik

Arduino Uno Board dapat dihubungkan ke sistem peraga berbasis LCD module $20 \times 4$ karakter berbasis HD44780 atau modul peraga atau display $20 \times 4$ character berbasis HD44780 menggunakan koneksi $\mathrm{I}^{2} \mathrm{C}$, sehingga dapat berfungsi sebagai sistem informasi data ke pengguna dengan menampilkan data-data hasil perhitungan (yang diolah di dalam Arduino Uno) dengan hanya menggunakan 2 (dua) kaki Arduino Uno (kaki A 4 dan $\mathrm{A}_{5}$ ) [3]. 


\section{METODE PENELITIAN}

Dengan menggunakan khasanah pengetahuan ilmiah seperti yang sudah dibahas pada paragrafparagraf sebelumnya dapat disintesiskan sebuah kerangka berpikir bahwa prototipe sistem yang diusulkan dapat direalisasikan dengan menggabungkan sistem rangkaian sensor tegangan efektif $\left(\mathrm{V}_{\mathrm{RMS}}\right)$, sistem rangkaian sensor arus efektif ( $\left.\mathrm{I}_{\mathrm{RMS}}\right)$ dari peralatan listrik, dan sistem penampil data ke Arduino Uno seperti ditunjukkan pada Gambar 4. Flowchart dari perangkat lunak yang dibuat untuk menghitung dan menampilkan nilai $\mathrm{V}_{\mathrm{RMS}}, \mathrm{I}_{\mathrm{RMS}}, \mathrm{S}_{\mathrm{AP}}$ (Daya Semu) ke LCD modul ditunjukkan pada Gambar 5.

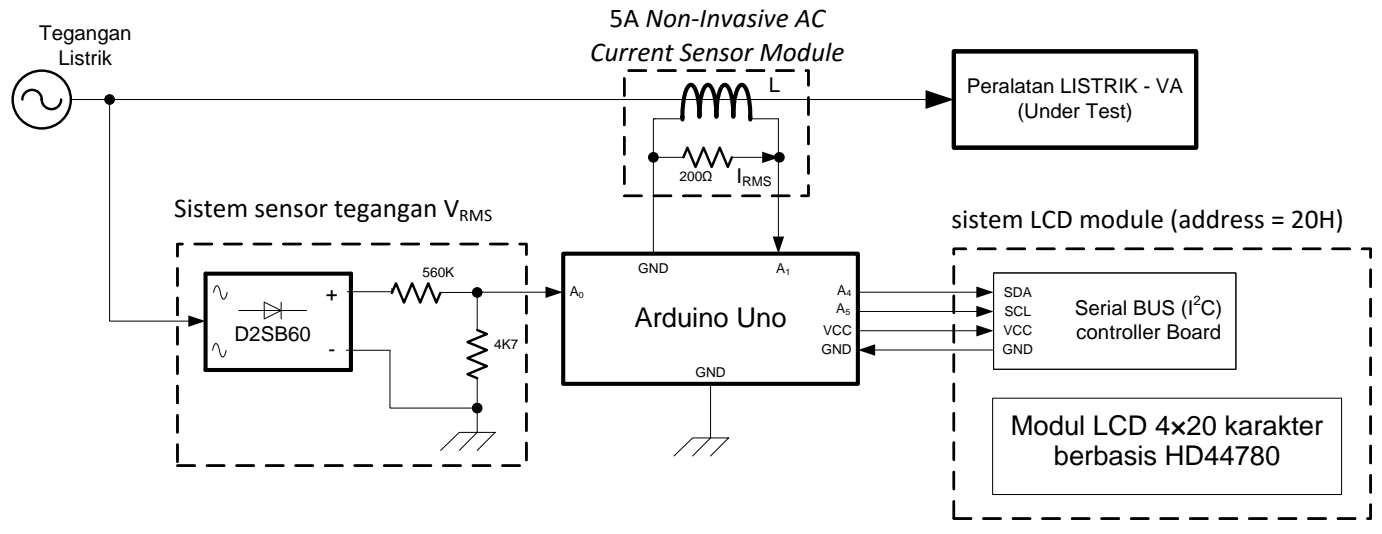

GAMBAR 4. Rangkaian Sistem pengukur daya semu peralatan elektronik berbasis Arduino Uno.

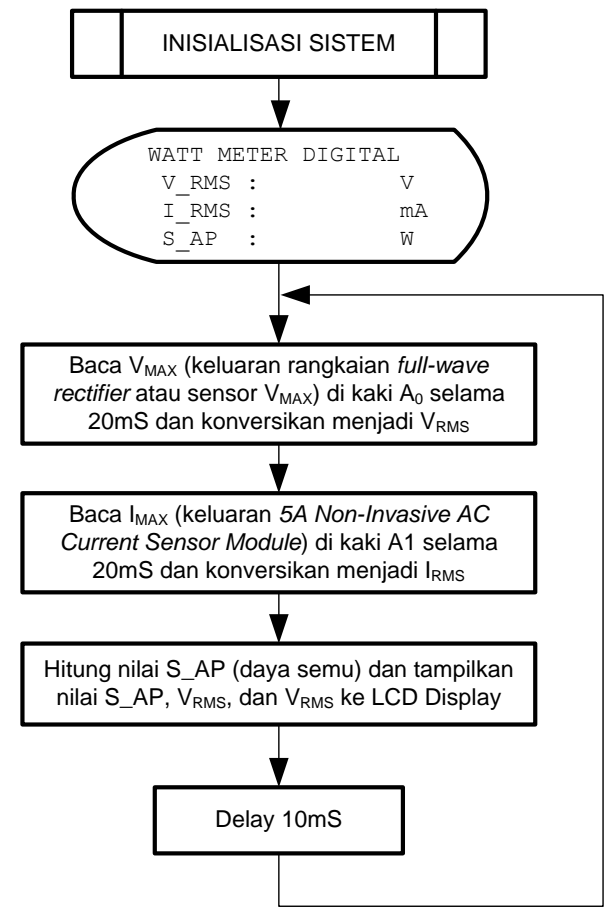

GAMBAR 5. Sistem pengukur daya semu peralatan elektronik berbasis Arduino Uno.

\section{HASIL DAN PEMBAHASAN}

Prototipe sistem pengukur daya semu peralatan listrik telah berhasil dibuat (bentuk fisiknya ditunjukkan pada Gambar 6). Hasil pengukuran dan pengujian pada beban (resistor-resistor) pada sub-sistem sensor tegangan $\mathrm{V}_{\mathrm{MAX}}$ adalah $\mathrm{R}_{1}=557 \mathrm{KOhm}$ dan $\mathrm{R}_{2}=4,65 \mathrm{Kohm}$. Susunan pengujian sensor tegangan $\mathrm{V}_{\mathrm{RMS}}$ ditunjukkan pada Gambar 8 dan bentuk gelombang keluaran di kaki $\mathrm{A}_{0}$ 
Arduino (saat sub-sistem sensor tegangan $\mathrm{V}_{\mathrm{MAX}}$ dihubungkan ke sumber tegangan listrik di Laboratorium Elektronika FT-UNJ) adalah sebesar 206,7 V $\mathrm{V}_{\text {RMS }}$ (Gambar 7.a). Hasil pengukuran rangkaian sistem sensor tegangan $V_{R M S}$ menggunakan USB PC-Oscilloscope Instrustar ${ }^{\circledR}$ ISDS 205B menunjukkan bahwa $\mathrm{V}_{\mathrm{RMS}}=1,685$ Volt $\left(\right.$ Gambar 7.b) dan hasil pengukuran tegangan $\mathrm{V}_{\mathrm{RMS}}$ menggunakan sistem berbasis Arduino Uno (menggunakan serial monitor) menunjukkan $\mathrm{V}_{\mathrm{RMS}}=1,71$ Volt atau mempunyai nilai \% error (kesalahan) sebesar $+1,5 \%$ sehingga sistem sensor tegangan $V_{\mathrm{RMS}}$ dapat disimpulkan telah berfungsi.

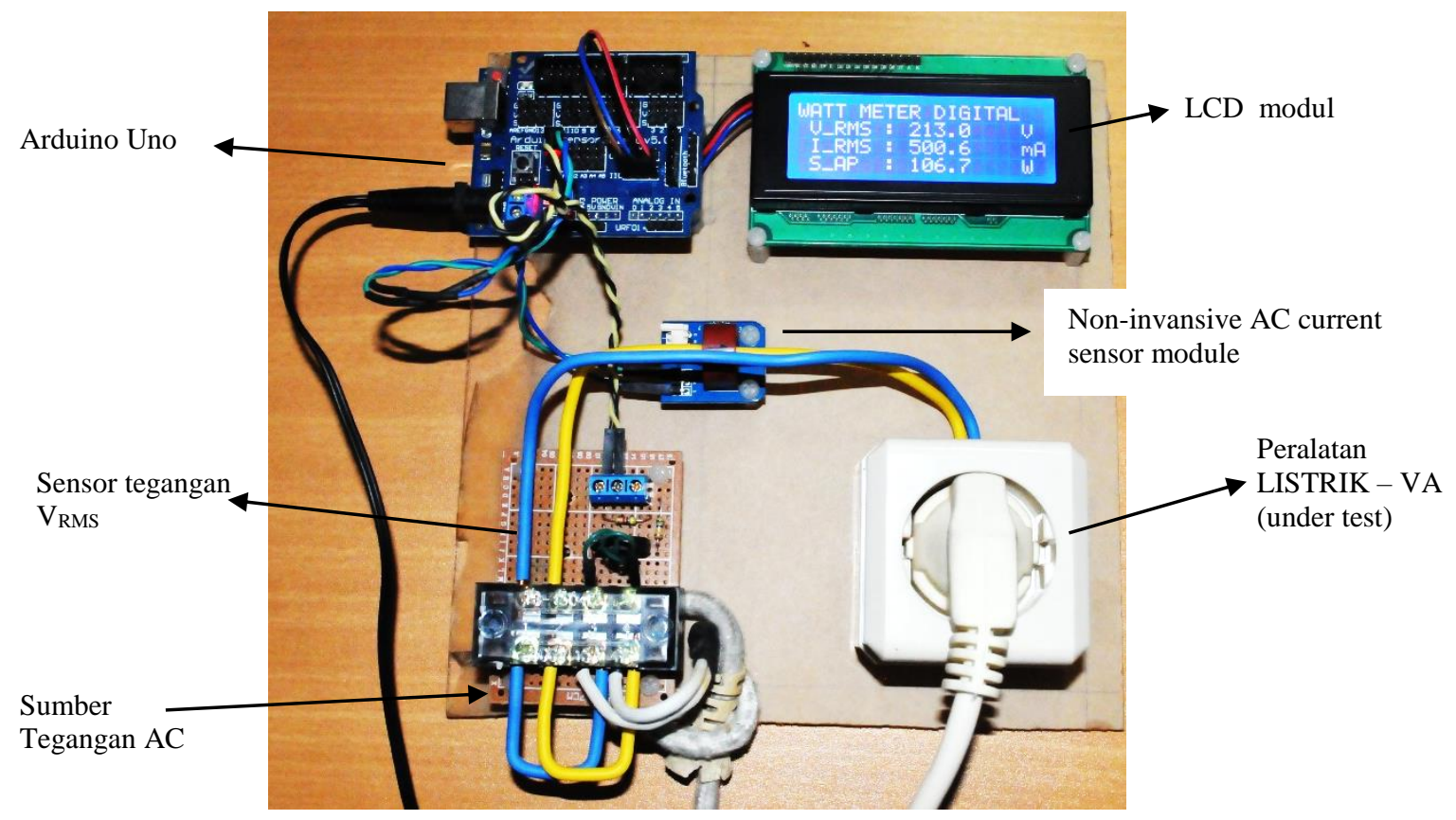

GAMBAR 6. Bentuk fisik prototipe sistem pengukur daya Semu peralatan listrik berbasis Arduino.

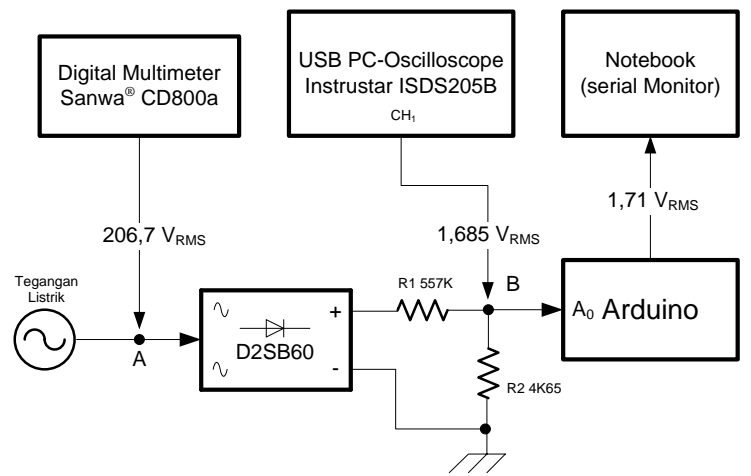

(a)

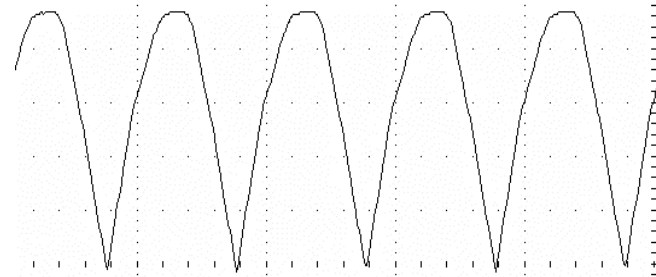

$\mathrm{Vpp}=2.444 \mathrm{~V}$ Vrms $=1.685 \mathrm{~V}$

Duty Cycle $56.5 \%$

$\mathrm{F}=100.000 \mathrm{~Hz}$

Cycle $10.000 \mathrm{~ms}$

(b)

GAMBAR 7. Hasil pengukuran dan pengujian sub-sistem sensor tegangan $\mathrm{V}_{\mathrm{MAX}}$, (a) bentuk tegangan keluaran di kaki $\mathrm{A}_{0}$ Arduino, (b) bentuk arus pada beban resistor.

Hasil pengujian dan pengukuran sub-sensor arus berbasis 5A non-invansive AC current sensor module saat dihubungkan ke setrika listrik (nilai daya di name plate : 315 Watts) ditunjukkan pada Gambar 8. Hasil pengukuran $\mathrm{V}_{\text {RMS }}$ adalah sebesar $305,207 \mathrm{mV}_{\mathrm{RMS}}$ (atau menghasilkan nilai $\mathrm{I}_{\mathrm{RMS}}=$ $305.207 \mathrm{mV}_{\mathrm{RMS}} \times 200 \mathrm{Ohm}=61041,4 \mathrm{~mA}_{\mathrm{RMS}}$ ) sedangkan hasil pengukuran $\mathrm{V}_{\mathrm{RMS}}$ (tegangan keluaran) menggunakan sistem pengukur arus berbasis Arduino Uno (menggunakan serial monitor) adalah sebesar $293,57 \mathrm{mV}_{\mathrm{RMS}}$ (menghasilkan $\mathrm{I}_{\mathrm{RMS}}=293,57 \mathrm{mV}_{\mathrm{RMS}} \times 200 \mathrm{Ohm}=58714 \mathrm{~mA}_{\mathrm{RMS}}$ ) atau mempunyai kesalahan pengukuran sebesar $-3,8 \%$ sehingga dapat disimpulkan sub-sensor arus $\mathrm{I}_{\mathrm{RMS}}$ telah berfungsi. 


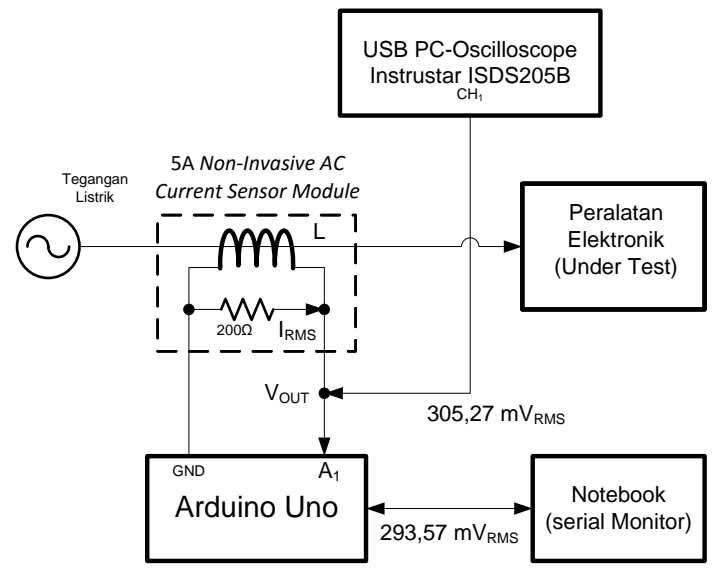

(a)

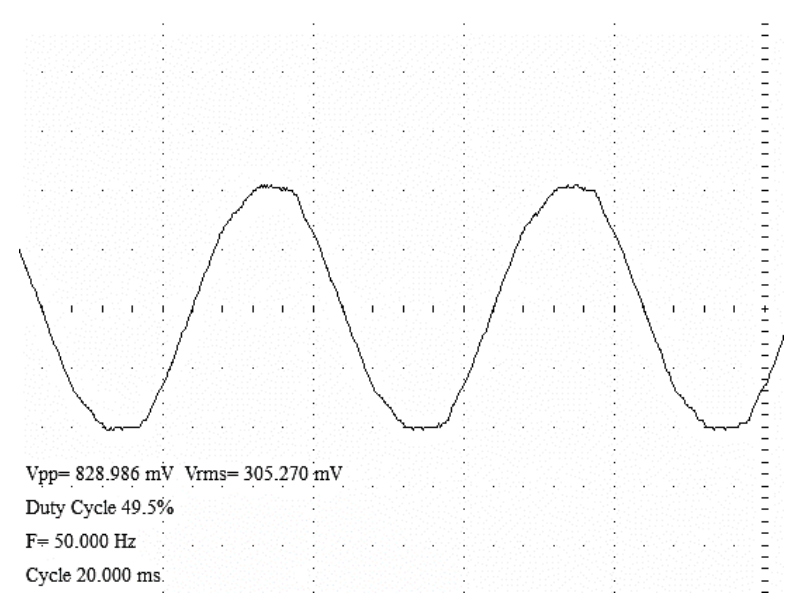

(b)

GAMBAR 8. Hasil pengukuran dan pengujian sub-sistem sensor arus $I_{M A X}$, a) Bentuk tegangan keluaran di kaki $\mathrm{A}_{1}$ Arduino, (b) Bentuk arus pada kaki $\mathrm{A}_{1}$ Arduino.

3 sub-sistem pengukur daya sudah selesai dibuat, diuji, dan sudah disimpulkan dapat bekerja sesuai dengan fungsi masing-masing dan telah dirangkai menjadi sebuah prototipe sistem pengukur daya peralatan listrik untuk kemudian digunakan untuk mengukur daya semu 11 peralatan listrik. Peralatan listrik yang diuji telah dikondisikan bekerja dengan beban penuh dan hasil pengukuran $\mathrm{S}_{\mathrm{RMS}}$ (daya semu) 11 peralatan listrik kemudian dibandingkan dengan hasil pengukuran menggunakan watt meter digital (multifunctional mini ammeter WanF® D02A) untuk mendapatkan nilai kesalahan pengukuran dalam \% (hasil pengukuran ditunjukkan pada Tabel 1). Kondisi pengujian untuk mendapatkan data-data hasil penelitian menggunakan tegangan sumber yang langsung dihubungkan ke jala-jala listrik PLN dan tidak menggunakan sumber tegangan AC yang stabil.

Hasil analisis data-data hasil pengukuran pada 11 peralatan listrik menggunakan prototipe sistem pengukur daya berbasis Arduino Uno dan menggunakan multi-functional mini ammeter WanF® D02A (Tabel 1) diperoleh fakta bahwa jika prototipe sistem digunakan untuk mengukur daya peralatan listrik rumah tangga yang mempunyai daya $<61$ Watts, maka nilai hasil pengukuran daya semu yang dihasilkan oleh prototipe sistem mempunyai nilai \% kesalahan pengukuran $>40 \%$, sehingga dapat disimpulkan prototipe sistem pengukur daya semu yang telah dikembangkan tidak disarankan untuk mengukur peralatan listrik yang mempunyai daya semu $<60$ Watts. Nilai $\%$ kesalahan pengukuran tersebut disebabkan karena tegangan keluaran atau $\mathrm{V}_{\mathrm{RMS}} 5 \mathrm{~A}$ non-invasive AC current sensor module tidak linier saat digunakan untuk mengukur arus $<200 \mathrm{~mA}_{\mathrm{RMS}}$ karena dikonversi menggunakan ADC-10 bit (ADC internal Arduino Uno).

TABEL 1. Hasil pengukuran daya semu 11 peralatan listrik rumah-tangga

\begin{tabular}{|c|c|c|c|c|c|c|}
\hline \multirow{3}{*}{ No } & \multirow{3}{*}{$\begin{array}{l}\text { Jenis Peralatan Listrik } \\
\text { rumah-tangga yang di uji }\end{array}$} & \multicolumn{4}{|c|}{ Hasil Pengukuran } & \multirow{3}{*}{$\begin{array}{c}\% \\
\text { error }\end{array}$} \\
\hline & & \multicolumn{3}{|c|}{ Prototype Sistem } & \multirow{2}{*}{ WanF® } & \\
\hline & & $\mathbf{V}_{\text {RMS }}$ & IRMS & $\mathbf{S}_{\mathrm{RMS}}$ & & \\
\hline 1. & Lampu LED Lightspro (3W) & $214,3 \mathrm{~V}$ & $51,8 \mathrm{~mA}$ & $11,1 \mathrm{~W}$ & $2,2 \mathrm{~W}$ & +404 \\
\hline 2. & Lampu LED OSRAM (9W) & $215,1 \mathrm{~V}$ & $155,4 \mathrm{~mA}$ & $33,4 \mathrm{~W}$ & $9,6 \mathrm{~W}$ & +248 \\
\hline 3. & Solder Listrik goot ${ }^{\circledR}(20 \mathrm{~W})$ & $213,9 \mathrm{~V}$ & $103,6 \mathrm{~mA}$ & $22,2 \mathrm{~W}$ & $24,2 \mathrm{~W}$ & $-8,3$ \\
\hline 4. & Electric Fan Krisbow (30W) & $218,5 \mathrm{~V}$ & $172,6 \mathrm{~mA}$ & $37,5 \mathrm{~W}$ & $25,4 \mathrm{~W}$ & $+47,6$ \\
\hline 5. & LCD-TV Samsung® 32 inchi (120W) & $209,3 \mathrm{~V}$ & $310,7 \mathrm{~mA}$ & $64,6 \mathrm{~W}$ & $61,6 \mathrm{~W}$ & $+4,9$ \\
\hline 6. & Heating Pad NUGABEST® $(120 \mathrm{~W})$ & $212,6 \mathrm{~V}$ & $500,6 \mathrm{~mA}$ & $106,5 \mathrm{~W}$ & $117,9 \mathrm{~W}$ & $-9,7$ \\
\hline 7. & Pompa Air Panasonic $\AA$ (250Watts) & $208,9 \mathrm{~V}$ & $1053,1 \mathrm{~mA}$ & $220,0 \mathrm{~W}$ & $201,3 \mathrm{~W}$ & $+9,3$ \\
\hline 8. & Setrika Listrik Phillips@ $(350 \mathrm{~W})$ & $201,4 \mathrm{~V}$ & $1398,3 \mathrm{~mA}$ & $281,6 \mathrm{~W}$ & $299,6 \mathrm{~W}$ & -6 \\
\hline 9. & Water Dispenser SHARP® $(350 \mathrm{~W})$ & $202,6 \mathrm{~V}$ & $1726,3 \mathrm{~mA}$ & $349,8 \mathrm{~W}$ & $349,3 \mathrm{~W}$ & $+0,1$ \\
\hline 10. & Rice Cooker Miyako (395W) & $212,2 \mathrm{~V}$ & $1622,7 \mathrm{~mA}$ & $344,4 \mathrm{~W}$ & $366,4 \mathrm{~W}$ & -6 \\
\hline 11. & Water Heater Ariston ${ }^{\circledR} 30 \mathrm{~L}(500 \mathrm{~W})$ & $208,9 \mathrm{~V}$ & $1691,8 \mathrm{~mA}$ & $353,4 \mathrm{~W}$ & $376,2 \mathrm{~W}$ & -6 \\
\hline
\end{tabular}




\section{SIMPULAN}

Berdasarkan hasil pengukuran dan pengujian dari prototype sistem pengukur daya (apparent power) peralatan listrik berbasis Arduino Uno diperoleh kesimpulan bahwa prototipe sistem yang diusulkan telah selesai didesain, dibuat, diuji, dan telah dibandingkan data-data hasil pengukurannya dengan instrumen pembanding (watt meter digital) multifunctional mini ammeter WanF® D02A dapat mengukur peralatan listrik yang mempunyai daya semu > 61 Watts dengan nilai \% kesalahan pengukuran daya semu $< \pm 10 \%$. Jika prototipe sistem pengukur daya digunakan untuk mengukur daya peralatan listrik rumah-tangga dengan daya $<61$ Watts, maka nilai \% kesalahan pengukuran nilai daya semu akan lebih besar dari $10 \%$.

\section{UCAPAN TERIMAKASIH}

Penelitian untuk mengembangkan prototipe sistem pengukur daya semu peralatan listrik ini dibiayai oleh dana BLU POK Fakultas Teknik Universitas Negeri Jakarta Tahun Anggaran 2016 berdasarkan SK Rektor UNJ Nomor : 583.a/SP/2016 Tanggal 29 Juni 2016, sehingga peneliti mengucapankan banyak terima-kasih kepada Dekan Fakultas Teknik Universitas Negeri Jakarta dan Lembaga Penelitian Universitas Negeri Jakarta.

\section{REFERENSI}

[1] Wikipedia.org, "Active, Reactive, and Apparent Power," in https://en.m.wikipedia.org/wiki/ AC_power\#Reactive_power, 1994.

[2] Storr, Wayne, "The Full-wave Rectifier", in http: //www.electronics-tutorial.ws/diode/diode 6.html.

[3] Djatmiko, Wisnu, "Prototipe Sistem Pengukur Kualitas Tegangan Jala-jala Listrik PLN," Proceeding Seminar Nasional Fisika 2016 Volume V, pp. 61-66, p-ISSN: 2339-0654 e-ISSN: 2476-9398, October 2016.

[4] Edminister, Joseph A., and Nahvi, Mahmood, “AC Power”, in Schaum's Outlines of Theory and Problem of Electric Circuits Fourth Edition, ISBN 0-07-139307-2, McGraw-Hill Companies, 2003, Chapter X, p. 150.

[5] Seedstudio, "Grove - Electricity Sensor," in http:// www.seedstudio.com/wiki/index.php? title=Twig_-_Electricity_Sensor, 2016. 
